\title{
Merchants and States: Private Trade and the FALL OF MADRAS, 1746
}

\section{Søren Mentz}

To cite this article: Mentz, Søren. "Merchants and States: Private Trade and the Fall of Madras, 1746." Journal of Indian Ocean World Studies 2, no. 1 (2018), pp. 36-56.

More information about the Journal of Indian Ocean World Studies can be found at: jiows.mcgill.ca

(C) Søren Mentz. This is an Open Access article distributed under the terms of the Creative Commons License CC BY NC SA, which permits users to share, use, and remix the material provide they give proper attribution, the use is non-commercial, and any remixes/transformations of the work are shared under the same license as the original. 


\section{Merchants and States: Private Trade and the FALL OF MADRAS, 1746}

\section{Søren Mentz}

Director, Museum Amager, Denmark

\section{Abstract}

Michael Pearson has argued that "rights for revenue" was an important element in the European way of organizing long-distance trade in the early modern period. The state provided indigenous merchant groups with commercial privileges and allowed them to influence political affairs. In return, the state received a part of the economic surplus. The East India Company and the British state shared such a relationship. However, as this article demonstrates, the East India Company was not an impersonal entity. It consisted of many layers of private entrepreneurs, who pursued their own private interests sheltered by the Company's privileged position. One such group was the Company servants in Asia. The French conquest of Madras in 1746 and the following period of British sub-imperialism in India demonstrate that the state had traded off too many rights. Through the business papers of Willian Monson, a senior Company servant in Madras, the historian can describe the fall of Madras as a consequence of deteriorating relationships between private interests within the Company structure. Directors, shareholders, Company servants and private merchants in India fell out with each other. In this situation, the British state found it difficult to intervene.

The fiscal needs of the states determined that they trade off revenue for property rights and indeed for other rights that also promoted growth, such as monopolies for trading companies, and a package of measures affecting trade. ${ }^{1}$

In the influential article "Merchants and States," Michael Pearson argued that "rights for revenue" was a key factor in the Western dominance of long-distance trade and one of the fundamental differences between Asia and Europe in the early modern 
period. For instance, the British state protected indigenous merchants by creating a commercial infrastructure and securing private property. Merchants received political rights and obtained social status in return for paying taxes and duties. A similar relation did not exist in the Mughal Empire. The financial needs of the empire could be met from massive amounts of land revenue, keeping the commercial sector out of the government's equation. The basic problem was that the Mughals had too much money to need to trade off revenue for rights.

In the period from 1500 to 1750, the European states were not always the leading force behind the creation of overseas colonies and commercial ventures. In many cases, governments were content with handing over the initiative to private entrepreneurs, providing adventurers and merchants with state licenses, but not with state support. As such, the Spanish Empire in Central and South America may be considered a vast "contracting-out system", a framework of government within which private individuals could proceed. British overseas activities operated along similar lines. As Kenneth Andrews once expressed, "the evidence we have hardly ever shows the crown or ministers on its behalf - taking the initiative, but rather responding more or less helpfully to private projects." ${ }^{2}$

Who were these private entrepreneurs, and how did they respond to the opportunities provided for them by the state? During the seventeenth and eighteenth centuries, the East India Company regulated trade between India and England. A royal charter secured the Company a privileged position at home and overseas, by excluding competition from other merchant groups. In the Indian Ocean and especially on the Indian subcontinent, the employees of the Company became a dominant commercial group, not as Company servants, however, but in their capacity of "private merchants." The private pursuit of mercantile profit led to the emergence of complex trade structures not only in the Indian Ocean but also between Asia and Europe well beyond those envisioned by the EIC directorate. ${ }^{3}$ Although private trade generated wealth the official interest of the Company, represented by the directors in Leadenhall Street, did not always correspond with the private interests of the men in India. This context was brought to light during the War of the Austrian Succession. In September 1746 French troops conquered Madras and threatened to oust the British from South India. Trade with England was disrupted, private merchants lost their money, and the British state faced serious financial problems, as the East Indian trade was one of the pillars, on which the British economy was based. In this situation, caught between different private interests, the government found it hard to intervene. Had the British state traded off too many rights in the eighteenth century? To answer this question the business papers of William Monson, a high-ranking

2. K. Andrews, Trade, Plunder and Settlement: Maritime Enterprise and the Genesis of the British Empire, 1480-1630, (Cambridge: Cambridge University Press, 1984), 360.

3. E. Erikson and P. Bearman, "Malfeasance and the Foundations for Global Trade: The Structure of English Trade in the East Indies, 1601-1833," American Journal of Sociology, 112, No. 1 (July 2006), 198. 
Company servant and a leading private merchant in Madras, are of great value, especially a document entitled "A Letter to a proprietor of the East India Company." ${ }^{\text {This document }}$ highlights the sentiments of the private merchants in Madras after the French conquest. They felt betrayed by the directors, and Monson's papers describe the rising conflict of interest between London and Madras. As such, the article will present conflicting private standpoints as a logical benchmark for British expansion in India in the period following the fall of Madras in 1746.

\section{Private Firm, Public Interest - The East India Company}

Historians have often described the chartered company as an innovative institution and emphasised two aspects which made the company historically unique. One was the ability to interact with the state which granted a group of private merchants 'semisovereign rights abroad and a national monopoly at home." 5 The East India Company could declare war, make peace and negotiate with foreign states in order to protect its commercial interests. Philip Stern has compared the Company-State in India with an early modern regime, "directed towards protecting a particular form of hybrid and composite sovereignty over a system that was at its core urban, coastal, and maritime in its orientation and rooted in the Company's constitution as a corporate body." ${ }^{\prime \prime}$

The other aspect emphasised by historians was the foundation of a permanent working capital and the establishment of the joint-stock principle, which deprived the shareholders of influence over their capital. The Board of Directors handled the daily administration. Its twenty-four members of the Board were responsible for investments, and they could concentrate on long-term goals, such as the reduction of transaction costs and ensuring a stable and continuous rate of profit. As Professor Niels Steensgaard remarked, "the Company transformed the gambler's profit of long distance trade into the safer, if less spectacular profits of conservative merchants."

The East India Company was a success, and the British state was aware of its importance to British prosperity. The trade with Asia raised customs revenues for the Crown and during the seventeenth century, the directors provided kings with capital. Charles II squeezed out $£ 50,000$ in 1666 and another $£ 70,000$ the following year, by promising to support the Company monopoly, and in 1709 the United East India Company lent

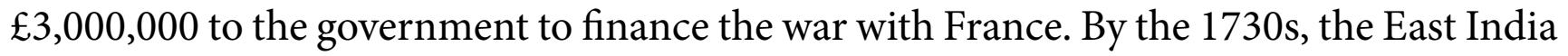

4. Lincolnshire Record Office (LRO), Monson Papers in the possession of Lady Monson, Manor House, South Carlton, Lincolnshire, MSS XXXV and LIII, Letter Books of William Monson.

5. K.N. Chaudhuri, "The English East India Company in the $17^{\text {th }}$ and $18^{\text {th }}$ Centuries: A Pre-Modern Multinational Organization," eds. L. Blussé and F. Gaastra, Companies and Trade, (Leiden: Leiden University Press, 1981), 30.

6. P. J. Stern, The Company State: Corporate Sovereignty and the Early Modern Foundations of the British Empire in India, (Oxford: Oxford University Press, 2011), 208.

7. N. Steensgaard, “The Companies as a specific Institution," eds. L. Blussé and F. Gaastra, Companies and Trade, (Leiden: Leiden University Press, 1981), 254. 
Company was no longer merely a commercial firm, but represented an economic power supporting the state with funds and was an object of investment for many Englishmen, who placed their savings in Company shares.

The merger of two East India Companies in 1709, concentrated power in a small group of wealthy stockholders well connected to the state and the City of London. The United East India Company issued short-term bonds worth $£ 2,300,000$ at a fixed rate of interest in order to raise capital. These bonds became popular investments, not only among merchants and brokers but also for the British middle class in general. East India stock became a "gilt-edged investment", offering an annual dividend of 6 percent and at the same time represented a secure investment. ${ }^{8}$

The Company was entering the public domain. Even though the directors were responsible for running the Company's affairs, they were obliged to consider the economic stability of the state. Their consideration of the investors became an important aspect in their decision-making policy. The South Sea Bubble in the 1720s demonstrated how losses on the Stock Exchange caused a public panic that placed the British state in a potentially dangerous situation. The stability of the Company became a topic which politicians discussed in Parliament and due to its significant role in British economy, government ministers tried to give "cast-iron guarantees of the Company's monopoly privileges to trade to the East, for the very same reason of confidence and stability." Cultivating the relationship with the state was always a priority for the Company, because its very existence depended on the parliamentary charter and the goodwill of the government. The years between 1709 and 1748 saw the East India Company in the strongest position it would ever enjoy, with respect to negotiations with the state, because its profitability enabled it to lend large sums of money to the government and reap its rewards in terms of support. ${ }^{10}$

The East India Company may have been the world's first multinational company, as stated by K.N. Chaudhuri, but it was run by people whose private interests played a significant role in its daily management. According to Richard Grassby, the East India Company was not led by a bureaucratic staff but by a "coalition of individual merchants, who identified for their own personal gain, the areas of greatest profit." ${ }^{11}$ Thus, indirectly, the rights-for-revenue-deal between the British state and the Company would necessarily include a range of private entrepreneurs who operated under the protecting umbrella of the Company stretching from the directors in Leadenhall Street to the employees in the factories in Asia.

8. H.V. Bowen, Elites, Enterprise and the Making of the British Overseas Empire, 1688-1775, (London: Macmillan 1996), 87.

9. P. Lawson, The East India Company. A History, (London: Longman, 1993), 76.

10. Ibid., 77.

11. R. Grassby, The Business Community of Seventeenth Century England, (Cambridge: Cambridge University Press 1995), 405. 


\section{Directors as Private Agents}

Indeed, as a director in strictness I ought not to know, that you carry on a trade directly in breach of your covenants. ${ }^{12}$

Edward Harrison was a member of the Court of Directors. He was also a private merchant involved in commercial activities in Asia. He knew better than any that Company servants were making money in India by competing with the very same firm that employed them. After a long career in India he was aware of the importance of private trade - his own personal fortune was a result of private trade - but in Harrison's opinion, the private sector helped to make the Company a stronger commercial organization. Thus, the success of the East India Company, in comparison with the contemporary chartered companies that failed, was its ability to incorporate private trade. The East India Company was not a modern hierarchically structured firm, but rather an umbrella organization, embracing private trade, and thus providing individuals operating within the monopoly, servants in the Asian factories, directors in Leadenhall Street, mariners onboard the East Indiamen and prominent shareholders, with opportunities to exploit the structure in pursuit of personal enrichment. ${ }^{13} \mathrm{~A}$ similar argument has been presented by Erikson and Bearman who argue that EIC's success in Asia was "the unintended byproduct of systematic individual malfeasance (private trading)." 14

Recruiting qualified merchants to positions in Asia was not difficult. The Company received numerous applicants, and educated men filled even inferior positions. Holders of subordinate positions such as "writers" in Madras, who did nothing but copy the correspondence of the governor and his council, could anticipate returning to England in the foreseeable future wealthier than when they left. The salary was meager, but private trade offered many economic opportunities. The trick was to stay alive long enough. As the French governor in Chandernagore, Francois Dupleix argued in 1731, "one dies here like flies, although it is well and good for making money." ${ }^{15}$ While the British governor of Bombay, Robert Cowan, remarked that only one among 50 lived to return home, and only one out of 10 of those came home with a fortune. ${ }^{16}$ The prospects of advancement within the hierarchy of the Company were good, and in time, a merchant might well become a member of the governor's council. However, the main attraction when joining the Company was the opportunity to launch a parallel career. Apart from their official

12. Public Record Office (PRO), London, C110/145, Adams vs. Boone, London, 10 April 1726, Edward Harrison to John Adams.

13. S. Mentz, The English Gentleman Merchant at Work. Madras and the City of London 1660-1740, (Copenhagen: Museum Tusculanum Press University of Copenhagen, 2005), 262.

14. E. Erikson and P. Bearman, "Malfeasance and the Foundations for Global Trade," 197.

15.I. Ray, "Dupleix’s Private Trade in Chandernagore," The Indian Historical Review, 1, No.2, (1974), 281.

16. Scottish Record Office, Edinburgh, AM Letters and Papers to John Drummond GD 24/1464 N, Bombay Castle 10 August 1733, Robert Cowan to John Drummond. 
duties, Company servants were able to participate in the Asian trading world, and private commercial networks emerged under the umbrella of the official structures, covering the Indian Ocean from West Asia to the Indian subcontinent, and further to China and the Philippines. ${ }^{17}$

Members of the Court of Directors used their power to appoint friends and business associates to positions within the Company structure. In many cases, private considerations and not commercial strategy dictated staff recruitment. Too many appointments were superfluous, and some of those appointed were considered incompetent when they began to work in India. In the beginning of the eighteenth century, the governor of Fort St. George (Madras), Thomas Pitt, complained about the rising number of persons in the Company's service. He argued:

By sending out so great number of factors and writers having here at this time three times as many as you have occasion for, besides some of them so refractory that I should willingly see them return to their friends as I believe their friends were glad to get rid of them. ${ }^{18}$

The directors did not respond to the formal protest from the governor of Fort St. George and continued the practice. In 1733, Lord Egmont paid a visit to Mr. Drummond, a director in the Company, to speak on behalf of his cousin, who wanted to enter the Company's service in Madras. Mr. Drummond began explaining how the positions in India were filled, but Egmont persisted: "On my desiring that favour at least might be shown him, he said he would do what he could, and bid me give him a note of my request before Wednesday." 19

Patronage was an important social element in British society and John Drummond was an influential person, having many clients in India who owed him loyalty and favors. Even the most senior merchants wanted to be on good terms with Drummond, and they would not deny his clients a helping hand. The system of patronage and the Company's official hierarchy could sometimes become conflictual. During the 1720s, John Roach was a member of the governor's council in Madras and, as such, a high-ranking Company servant, and yet Roach was also one of Drummond's clients. He tried to serve both. As he explained to his patron: "I humbly desire the continuation of your friendship and patronage whilst I continue to serve the Company with honour and fidelity in whatsoever station I am in." 20

17. S. Mentz, "European Private Trade in the Indian Ocean, 1500-1800," ed. O. Prakash, The Trading World of the Indian Ocean, 1500-1800, (New Delhi: Pearson 2012), 486.

18. British Museum Add MSS 22847, Letter Book of Thomas Pitt, Fort St. George, 9 February 1703, Thomas Pitt to the Court of Directors.

19. P. Lawson, The East India Company, p. 72.

20. Scottish Record Office, Edinburgh, AM Letters and papers to John Drummond, GD 24/1/464 N, Fort St. George 11 January 1728, John Roach to John Drummond. 
It is helpful to study the structure of the East India Company as multiple sets of private interests. Directors looked after the general interest of the Company and cooperated with the government in this respect, but directors did also look after their personal interests. In this respect, the directors resembled the Company servants in India.

\section{Private Trade - The Indian Ocean}

The monopoly of the East India Company included trade in the Indian Ocean. However, in 1665 the Company abandoned its activities in Asia, the so-called country trade, and left the scene for its employees to exploit. In the century that followed, private trade expanded, and British merchants emerged as the most successful Western traders in the Indian Ocean. Within the structure of the Company, a private sector emerged. Madras, Bombay and Calcutta, the three major settlements of the East India Company, became regional centers of trade and connected with major commercial emporia in the Indian Ocean. In Madras, the custom revenue levied on country trade increased. "Sea customs" were imposed by the Company on all goods imported to Madras and according to Charles Lockyer, the merchants paid five per cent ad valorem.$^{21}$ In 1706 , sea customs raised just below 20,000 pagodas, and the value increased in the following decades reaching 30,000 pagodas in the 1730s. The information in the Diary and Consultation Books of Madras indicates a similar rise in departures and arrivals of country trade vessels, while the number of Englishmen living in Madras increased from 39 in 1678 to 114 in $1723 .{ }^{22}$

The British private sector in Madras included two social groups, one being Company servants and the other being "free merchants", individuals not employed by the Company, but with permission to reside in the East in order to trade or find employment as sailors and supercargoes on private vessels. The private sector was under the control of the directors in London and the right to levy taxes on the private trade secured the Company a part of the commercial surplus generated in the Indian Ocean.

The growing private sector in Madras is documented in letter books and accounts from the period. Nathaniel Chomley's account book from 1682 reveals his involvement in trade from Madras to Bengal, Banten and Manilla, while his friend, Robert Freeman, was involved in trade with Persia and China. ${ }^{23}$ Thomas Pitt, the governor of Madras from 1698 to 1709, concluded a regular trade with China using his son, Robert, as supercargo and dispatched goods to Bengal and along the Coromandel coast through his personal networks of commissioners in places such as Masulipatnam and Vizagapatnam. When Joseph Collet became governor of Madras, he told a business associate in 1716, "you can hardly believe it possible for a man to be so soon engaged so deep in trade as I already am

21. C. Lockyer, An Account of the Trade in India, (London 1711), 9.

22. S. Mentz, The English Gentleman Merchant at Work, 198-202.

23. S. Mentz, "English private trade on the Coromandel coast, 1660-1690: Diamonds and country trade," The Indian Economic and Social History Review, XXXIII No 2 (April-June 1996), 158-160. 
in shipping to almost all parts of India." ${ }^{24}$ His statement is supported by Charles Lockyer, who claimed that Madras merchants were trading with Batavia, Java, Johore, Melaka and Arakan, and continued, "but of late, their greatest ships use the Mocha, Persia and Surat markets with Bengal or China markets." ${ }^{\text {" }}$

Participation in the Asian country trade produced reasonable dividends and wealth was generated through careful investments. In 1709, Elihu Yale, who served as governor in Madras in the 1690s, wrote the following advice to a young merchant, "you must not be impatient in your progress nor make too much haste for riches, which too often makes a melancholy disappointment, my fortune cost me near 30 years of patience." ${ }^{26}$ When it came to earning money, Yale knew the terms. He amassed a fortune of over $£ 100,000$ in the course of his stay in Madras. The private merchants prospered under the loose structure of the East India Company and created an international commercial network. "Private traders wove local interactions into a global institution (the EIC) creating the dense structures we associate with globalizing processes on the back of the existing trade infrastructure."27

\section{Expanding the Scope - Private Trade Between Madras and London}

The private merchants were constantly expanding their network and tried hard to include Europe. The City of London was the most lucrative market and transcontinental trade generated the dividends necessary to establish a personal fortune. In addition, a significant part of the money involved in country trade seems to have originated in London. This cash flow between London and the private merchants on the Coromandel coast was the foundation of the country trade sector and it helped to establish a local British capital market in Madras. British capital arrived in Madras through several channels. The obvious way was bringing out initial capital. When William Monson arrived in Madras in 1725, he carried approximately $£ 1000$ with him and told his father that it was the best way of launching a career. "There can be no working without tools" was a frequently used remark in connection with initial capital. ${ }^{28}$ It is difficult to assess the amount privately brought to India by Company servants. In spite of the secret nature of such arrangements, the private network was small, and it was easy to obtain information regarding the creditworthiness of newly arrived persons. William Monson claimed that "everybody here knows what money a gentleman has sent him out, nay are diligent to enquire into so that before you come to be much concerned in trade your circumstances

24. OIOC, Mss. Eur D 1153, Private Letter Books of Joseph Collet, Vol. III, Fort St. George 14 December 1716, Joseph Collet to John Bedwell.

25. S. Mentz, "European Private Trade in the Indian Ocean," 501.

26. PRO, London C108/299, “Estate of Catherine Nicks," London 1 January 1719, Elihu Yale to Elihu Nicks.

27. E. Erikson and P. Bearman, "Malfeasance and the Foundations for Global Trade," 227.

28. BM, Add MSS 22849, Letter Book of Thomas Pitt, Fort St. George, 19 September 1706, Pitt to Ettrick. 
are partly known." ${ }^{29}$ Prominent merchants appointed to high posts in the service of the Company arrived with substantial sums, whereas the greater part of the lower-ranking personnel arrived with modest means. As such, private capital circulated between Madras and London.

Since the foundation of the East India Company, private trade had been an integrated part of the commercial structure. During the second half of the seventeenth century, the diamond trade was the most important branch of the private operations between Madras and London. The Coromandel coast was an important region for the diamond trade and merchants in Madras acted as private commissioners for their partners in London. Silver was loaded onto Company vessels privately and sent to India under the care of the ship's captain or other high-ranking officers. In Madras, a local British commissioner received the capital, bought the diamonds and dispatched them back to London. For this job, the private merchant was paid a commission fee. Most of the capital was entrusted to respectable private merchants, who found themselves in an ideal position to make money. Access to the City of London provided the commissioner with cash and a lucrative market restricted to a very few. In India, the commissioner could combine investment in Asian country trade with financial activities such as money lending and insurance business. These influential private merchants spearheaded the British expansion in the Asian trading world, providing capital and commercial opportunities to small-scale merchants. ${ }^{30}$

\section{The Agency Problem}

The East India Company began to deal with the so-called "agency problem" in the years after 1709 as an attempt to bring together the multiple sets of interests through coercion. Hitherto, private trade was considered a natural component of overseas trade but with the merger of the two Companies and in regard to the Company's economic position within the British state, it became necessary to limit the number of private entrepreneurs who stood to benefit from the right-for-revenue-deal. The first target was the commercial network between private merchants in Asia and their commissioners in London.

The United East India Company introduced strict regulations about private trade. Company servants were not permitted to carry private capital to India and trading activities with London were curtailed. Private merchants were encouraged to concentrate on country trade activities and leave the Company to supply the home market. Bills of exchange drawn on the Company's headquarters in London became the only legal way to remit capital from Madras to England.

William Monson, who arrived in Madras in 1725, felt the changing attitude 
towards private trade. Before his departure from London, the former governor of Fort St. George, Edward Harrison, informed him about the ways to make money in India. Harrison advised him to concentrate on financial activities with London, thus investing in respondentia bonds and private bills of exchange. Once in Madras, however, Monson found no market for these transactions and informed his relatives in England that "the captains \& officers in the ships are so striated in their privileges themselves now that makes them very unwilling to carry anything for private people except their particular friends." ${ }^{31}$ Monson wondered why the directors reduced private trade with England when capital from London was the very foundation of the British country trade sector in Madras. The French Company, he observed, allowed its servants to draw capital to the East and due to its liberal-minded directors, the French had "risen in a few years from a very small figure of credit in India to be our rival in every port."

The attempts to solve the agency problem in India was a new departure. Before the 1720 s, it would be fair to argue that the director's approach to private trade in India and the private connection with London had been low-key. According to Huw Bowen the change was due to, "the unregulated enterprise and expansion [of private trade] was now threatening the security and stability of the greater imperial whole." ${ }^{32}$

Henry Powney was a free merchant in Madras and he was very disappointed with the directors. The regulations affected his opportunities of remitting money to England and that was a discrimination because it affected the free merchants more then the Company servants. In 1739 he declared to a friend in London:

I have been above thirty eight years an inhabitant of this place and for thirty years" time have been commander and super cargo and have paid the Company more custom than a great many of their servants put together, therefore think they ought to give me the same indulgence as they give their servants that is to pay my money into their cash at seven shilling and eight pence for the pagoda. ${ }^{33}$

The actions taken by the East India Company were directly opposite to the rules laid down by the French. During the 1720s, the directors of the French Company recognized the need for private capital in Asia and accepted these transactions taking place. As Catherine Manning has observed: "The French needed capital from home to initiate their projects and display creditworthiness to the commercial communities of their regions." ${ }^{34}$

Directors and private merchants disagreed. If the state had traded off rights for revenue to the Company, who among the many private entrepreneurs could expect to share the profits? A completely new mindset was introduced, and it disturbed the mutual

31. LRO MSS XXXV, Letter Book of William Monson, William Monson to Lord Monson, undated latter.

32. H.V. Bowen, Elites, Enterprise and the Making of the British Overseas Empire, 190.

33. PRO C111/95, Correspondence of Thomas Hall, Fort St. George 26 January 1739. Henry Powney to Thomas Hall.

34. C. Manning, Fortunes á faire. The French in Asia Trade, 1719-1748, (London: Variorum 1996), 103. 
understanding between the Company servants in Asia and the directors in London. Unfortunately, the changes occurred in a period characterized by political instability in South India and in Europe. An unforeseen consequence of the new rules was that Company servants in Madras did not feel obliged to follow the orders they received from London and began to find alternative ways of making money. The French conquest of Madras in 1746 marked this shift in loyalty. Through the event we can observe how loyal Company servants were transformed into headstrong individualists in pursuit of their own interests. William Monson's letter books offer an eyewitness account of the changing attitude of the private merchants in Madras and how "rights for revenue" brought not only the East India Company but also the British state to great peril.

\section{Company Servant - Private Merchant. The Career of William Monson}

As a younger son of a British lord, William Monson needed to make a professional career. He, or rather his father, chose an employment in the East India Company. Before setting out for Madras, Edward Harrison, one of the directors of the Company, promised to be the young man's commissioner in London. Further, he advised Lord Monson to provide William with substantial initial capital in order to put him on the right track as soon as he arrived on the Coromandel coast.

William Monson's future looked bright, however once in Madras, his prospects turned sour. In the first decades of the eighteenth century, the trading world of the Indian Ocean was under pressure. Markets failed in the Red Sea and in the Persian Gulf, and India suffered from political after the death of Aurangzeb in 1707. Shortly after his arrival, William Monson made a bad investment. Although he lost most of his working capital, he managed to save his reputation among the town's Indian financiers. Apparently, the substantial sum of money he initially brought with him had impressed the inhabitants of Madras and they took him for a promising merchant who could regain his economic status through his connections with the City of London. As such, Monson managed to continue his private investments in Asian shipping, although he had lost most of his own money. He argued that the support he maintained from Indian merchants was in their own self-interest, and elaborated the statement in a letter to his father:

For what they have of my friends and family in England and the particular notice Mr. Pitt was pleased to take of me when he was up here last year makes them think I shall be a great man by and by. ${ }^{35}$

Although Monson downplayed the losses, his financial situation must have been poor, for later in the same letter, he begged his father to consign more silver to Madras. Monson needed "ready money" to finance his commercial activities and to 
support his social life. The letter shows how connections with London strengthened the creditworthiness of a private merchant. Prestige was as important as cash: "for it is credit with them that enables many people to carry on the trade they do, many having often many times more money at sea than they themselves are worth", Monson argued. ${ }^{36} \mathrm{He}$ stressed the fierce competition among the young British merchants, who were shipped off to India in the hope of social advancement:

There come from England every year so many free merchants recommended to each of our presidencies in India by their respective friends at home whom they must oblige in such things that they are forced to make up voyages and ships to some port or other to put them in employ. ${ }^{37}$

William Monson's early letters are informative. He was unfamiliar with commercial activities in the Indian Ocean and so was his father. The intention of the letters was to provide Monson's family with detailed information about the trade and social attitudes of the British community in Madras. One important aspect described in the correspondence is the private trading circles between Madras and the City of London. Consignments of silver were shipped to India privately in the care of the captains and officers on board the Company's ships. "If I should in the course of my business remit a considerable sum to England and desire the return to be made in silver, you may take this method", wrote Monson to his brother in 1729. He also warned him: "I need not to caution, this is not to be communicated to any of the directors or their officers and only to persons who undertakes to carry it." ${ }^{\prime 3}$

The business correspondence provides us with a rare glimpse of the trading world of the private merchant. Initial capital and consignments of silver from London raised Monson's creditworthiness in India and provided him with capital to invest in commercial ventures in Asia. Whenever there was a chance to trade with England, Monson invested in goods, primarily uncut diamonds, bills of exchange or in respondentia bonds. Beside his private activities, Monson worked for the East India Company and advanced in seniority. He was promoted to second in the Madras Council and became the senior most Company servant after the governor. This seemingly bright future was then hampered by the French conquest of Madras in 1746.

\section{The Fall of MAdras, 1746}

The War of the Austrian Succession broke out in March 1744 and involved Great

36. LRO Monson Papers MSS LIII Letter Books of William Monson, Fort St. George, 24 January 1727, Monson to his father.

37. Ibid.

38. LRO, Monson Papers, MSS LIII Letter Book of William Monson, Fort St. George 10 February 1729, Monson to his brother. 
Britain and France. News from Europe reached Madras in September when François Dupleix, the French governor of Pondicherry, proposed a general peace in the Indian Ocean between the East India Companies. The governor of Fort St. George, Nicholas Morse, claimed not to be authorized to enter such a contract, although peace in India had been the general practice in previous Anglo-French wars. His hesitation was caused by the information he received from London. The directors had requested the government to dispatch a naval force to the Indian Ocean, and a fleet under the command of Curtis Barnett had already left. As an officer in the Royal Navy, Barnett could make private money by capturing French commercial vessels, and the private interests of the navy officers would most likely disrupt the peaceful trade in the Indian Ocean. Thus, the war brought yet another group of "private entrepreneurs" to the region, the European "Statesoldier." Under normal circumstances, private merchants of different nationalities would keep the peace, but good intentions were hard to follow with the arrival of European battle ships in Asian waters. At first, Nicolas Morse managed to dissuade Barnett from attacking Pondicherry, claiming that such an action would be considered offensive towards the Indian rulers. ${ }^{39}$ Barnett died of fever 29 April 1746, and soon after his successor sailed off, possibly in search of French vessels to capture. The departure left Madras military exposed and the situation worsened when a French squadron of five ships and 3300 soldiers arrived at Pondicherry under the command of Bertrand-François Mahé, comte de La Bourdonnais. He was the governor of Isle de France and had been summoned to the Coromandel coast by Dupleix. French troops initiated a siege on 4 September occupying the Company's garden where they constructed a battery of ten mortars. At close range to Madras the French opened fire on 7 September.

The situation in Madras was desperate. The British soldiers were ill disciplined and offensive. According to Mr. Cole, a member of the governor's council:

The soldiers were quartered on the points and batteries of the black town and were daily fed with good provisions and arrack given them for punch, besides drams every day; and yet notwithstanding the most favorable treatment the English soldiers were every day more insolent and threatened to mutiny. ${ }^{40}$

Constant fears of falling bombs caused panic and so "fatigued the gentlemen that they were ready to die for want of sleep." ${ }^{41}$ The bombardment continued and on 9 September, the British began to negotiate a peace settlement with La Bourdonnais. William Monson represented the council and was seconded by John Hallyburton, who spoke fluent French. On 15 September, they reached an agreement. On behalf of the East India Company, Nicholas Morse promised to pay a ransom of $1,100,000$ pagodas, or $£ 481,250$

39. H.D. Love, Vestiges of old Madras, vol. II, (London: John Murray 1913), 340-75.

40. “The Narrative of Mr. Cole," Ibid., 358-9.

41. Ibid., 358. 
to the French Company. The Company servants surrendered Madras to the forces of La Bourdonnais, but the town would be restored to the British as soon as the director in London accepted the terms and paid the ransom. In the meantime, the inhabitants would not be molested, and neither the property of the Company nor private goods would be confiscated.

François Dupleix did not accept the agreement. In his view, the conquest of Madras marked the exclusion of the British from South India, and by destroying their trading facilities, the French would eliminate a serious commercial rival. The trouble the Governor of Pondicherry made delayed the treaty and it was not officially signed until 10 October. By then, La Bourdonnais was in a hurry to close the agreement expecting to make a private profit for having defied Dupleix and secured the British the opportunity of restoring the town through ransom. He demanded 100,000 pagodas which the private merchants accepted fearing for their property. La Bourdonnais received 88,000 pagodas in cash, pearls and diamonds before he left India. Later, Nicholas Morse regretted this arrangement lamenting, "that no receipt was taken or required for the money privately paid nor could any be insisted on in such a transaction, nor was any agreement made for returning the 88,000 in case the treaty was rejected by the governor of Pondicherry." ${ }^{42}$

La Bourdonnais left the Coromandel coast on the 12 October. On 30 October, Dupleix declared the treaty void and took possession of Madras on behalf of the French East India Company. All British property was confiscated and the Company servants who did not manage to escape were sent to Pondicherry as prisoners. The official ransom was never paid, and the French Company occupied Madras through the rest of the war. The Treaty of Aix-la-Chapelle (1748) returned Madras to the British, but the town was severely damaged, and the occupation had been a costly affair for the Company. Neither the directors nor the shareholders were pleased. Who was responsible for the dreadful losses?

\section{A Letter to a Proprietor}

"A Letter to a Proprietor of the East India Company" is a compilation of material written or collected by William Monson between 1747 and 1749. It consists of more than 100 handwritten pages, including appendices and extracts from various documents. ${ }^{43}$ William Monson was very concerned about the situation in Madras and sent a petition to the King on behalf of himself and his former colleague, governor Nicholas Morse. The final document is kept in the Oriental and India Office Collection. ${ }^{44}$ The document is Monson's personal account of the loss of Madras in 1746 and his views on how this

42. Ibid., 370 .

43. The draft and other documents used to make the letter is preserved at Lincolnshire Record Office, LRO, Monson Papers, MSS LIII Letter Book of William Monson, "A Letter to a Proprietor in the East India Company."

44. OIOC, MSS EUR E 246, "The memorial of William Monson late second of council in service of the East India Company at Fort St. George on behalf of himself and his partner Nicholas Morse late governor." 
affected the interest of the private merchants. His description is interesting because it focuses on two changing relationships: the first between the British government and the Company, and the second between the Company and the private merchants. Prior to 1746 private trade was regarded as one of the factors behind the British commercial success in Asia, and private merchants shared the advantages provided by the rights-for-revenue deal. This arrangement changed, not only for private merchants in Madras but for the British Empire as a whole. According to Huw Bowen "before 1750, the metropolitan elite and the overseas elite had for the most part marched to the same general tune. Thereafter, they increasingly began to fall out of step with one another." ${ }^{35}$ As the government began to intervene in private spheres, it weakened the unity of the empire it was trying to preserve. This change is articulated by William Monson in his letter to a proprietor.

\section{The Loss of Private Property}

William Monson lost everything in 1746. His home, his warehouse, and his personal fortune, without receiving any kind of compensation. He and other petitioners hoped the King would intervene on their behalf and demand satisfaction from the Company. The claims put forward in the petition was: "That your memorialist and his partner were by this violent and unwarrantable breach of faith dispossessed of a very considerable estate in merchandize and effects to the amount of pagodas 72218 or $£ 27,683$.”

William Monson managed to escape the French and avoid prison. He returned to England in 1747 only to discover that the directors were trying to discredit their employees in Madras by accusing them of cowardice. Leadenhall Street argued in public that timid Company servants had surrendered the town to the French, agreed to pay a horrendous ransom, and even paid La Bourdonnais $£ 100,000$ under the table. The directors were not prepared to reimburse the losses and considered prosecuting the responsible employees. In this situation, Monson began to write his own account, accusing the directors of misconduct. He addressed the statement "to a proprietor", a shareholder of the Company, and a person with economic interest in the affair. His main argument was that the directors never understood the true value of Madras. It was much more than a port of call where the Company stored goods and loaded homebound ships. Private merchants had transformed the settlement into a thriving commercial port that generated wealth and prosperity, but the directors ignored the development because they only concerned themselves with affairs in London. Preserving the best relations with the government and to satisfy the shareholders were top priorities. In Monson's opinion, the directors' interest in shortterm success meant sacrificing long-term investments in Asia. Greed, not cowardice, he claimed, was behind the fall of Madras, and it was the greed of the directors in London. To secure stability in England, and satisfying the shareholders, the directors had raised

45. H.V. Bowen, Elites, Enterprise and the Making of the British Overseas Empire, 178. 
the annual dividend from seven to eight percent. It would have been wiser to reduce the dividend to six percent and invested the surplus in securing the Company settlements in India, Monson argued. The Subcontinent was troubled with political unrest. The Mughal Empire was splitting up as provincial governors and local power brokers challenged the centralized government in Delhi. In 1738, the Persian general Nadir Shah invaded North India, looted the capital and left the Mughal territory in a state of political turmoil. Faced with general unrest the Company servants turned to London for help, but the directors did not send military assistance to India and additional funds were set aside to improve the defence of the Company towns. Not even when a Maratha army invaded the state of Arcot and threatened to attack Madras, did the directors change their minds. Monson wrote:

But the objection to that doubtless was that it would lessen the profits, they made by having the surplus tonnage home at half freight and perhaps a ship or two might have remained in India upon demurrage, and so for the sake of the paltry saving, all their settlements in India were left exposed to every invader; there was no danger abroad which seemed alarming enough to take off the attention of the gentlemen who were safe in Leadenhall Street. ${ }^{46}$

It was not only the political instability in India, but also the rise in French commercial activities that concerned the Company servants. On several occasions, they informed the directors of the increase in shipping activities in Pondicherry and although they received orders to take measures against the French, no aid was sent from London. William Monson could not understand the policy:

It could not be the want of money for they had been passing every year at the general court how much their savings was increased and their own merit for so prudent a conduct; what was it them? The directors will say perhaps the ships they sent out had not room and convenience to carry more men and warlike stores; I ask them why did they not sent out more ships ${ }^{17}$

According to William Monson, the focus on domestic affairs left Madras exposed to any invader, Asian or European. True, a squadron of war ships was dispatched to Asia, but the intention was not to protect Madras and the other British settlements in India. The directors and the government "calculated only for a cruising scheme", seizing French ships or preventing the enemy from taking British prizes. The letter continued:

46. LRO, Monson Papers, MSS LIII Letter Book of William Monson, "A Letter to a Proprietor in the East India Company." The following quotes in the section are taken from the same letter. 47. Ibid. 
In this manner were the proprietors lulled, as it were asleep, and into such a dependence upon the veracity of the directors, as to believe their affairs were in a safe and happy situation; but these were only as to the directors to keep up the price of the stock in which they indeed succeeded, until the news arrived that Madras was actually taken by the French, then the stock fell considerably, and the directors were then to act a new scene of deceit, not only to exculpate themselves from the blame of having so shamefully neglected the place, but also to raise again the value of the stock in which last they could succeed, they flattered themselves the proprietors would soon become indifferent about particular accidents and that then they would be restored to such credit as would be sufficient to enable them to propagate every story about Madras as they saw fit. ${ }^{48}$

When the fall of Madras became known in England, the directors told the shareholders that losses inflicted upon the Company were modest, only $£ 70,000$, "and they spoke with such an air of indifference", Monson claimed, "as if the loss of Madras had been of no more consequence than the loss of one of their ships." 49 The directors began to spread a rumour in London's coffeehouses that Madras had surrendered without resisting, and that no actual fighting had occurred due to the cowardice of the Company servants. William Monson blamed the directors for this false accusation. In his opinion, they feared that the size of the ransom would create a panic on the stock exchange, and argued that, "the directors seemed to bless themselves that the French had broken the treaty and Mr. Dupleix was frequent mentioned as the saviour and preserver of the Company by his violation of it." ${ }^{50}$ The directors would have refused to pay the ransom because the private merchants stood to lose much more than the Company. Thus, they sacrificed Madras.

Was the ransom too high? Not in Monson's opinion. But the directors neglected the fact that Madras was a central port in the Indian Ocean and as a leading market, it generated valuable revenue to the Company. Instead of criticizing the private merchants, the directors should salute the achievements that had transformed a minor Company factory into a flourishing commercial entrepôt. Monson elaborated:

In a word Madras had become the administration of all the country people and the envy of all European neighbours; and as it had for a great many years brought in a clear annual revenue of near 70,000 pagodas, a sum far exceeding the whole charges of the place civil and military according to your establishment in peace, a sum that would have defrayed all the civil expenses of the government and maintained above 1200 Europeans with proper officers and arms for its defense 
in War..$^{51}$

For the past twenty years Madras had been profitable and an asset to the East India Company. The customs revenue from country trade activities, the financial transactions and the silver coinage generated a surplus of near 90,000 pagodas a year. If Madras and its inhabitants had remained in this flourishing state and avoided destruction by paying the ransom, Monson argued,

we should most probably as we had for the three proceeding years invested on the Coast full 500,000 pagodas a year, have made good our obligations to the French for the three years to follow at 200,000 pagodas a year, and had sent you each year 3000 bales beside the profit were on, I will venture to affirm would much more than have paid that part of the ransom which was contracted should be paid in Europe. ${ }^{52}$

In conclusion, Monson argued that the policy of the East India Company was wrong. The directors were too concerned with domestic affairs and neglected the private interests of the Company servants in India. Private trade had raised Madras from an insignificant Company outpost to a flourishing port town generating wealth. The directors should have nursed the private sector in Madras and continued to allow different sets of private interests to flourish under the structure of the Company. Investment in Madras was needed, Monson argued:

Had it been applied for the protection of the place, it would have prevented much if not all of the mischief that has lately happened; but instead this too great part was remitted to England to augment the dividends at home; it was an income that under proper management would have increased and with proper care the English would have continued to have reaped the benefit of so long as they had continued to be a trading company. ${ }^{53}$

William Monson remained in England for the rest of his life and did not experience the dramatic expansion of British power in India during the second half of the eighteenth century. The continuance of the rivalry between the French and the British in South India, often personified by Clive and Dupleix, the battle of Plassey, and the conquest of Bengal transformed Company servants into empire builders. They began to "shake the pagoda tree" and amass individual fortunes through disobedience and abuse of power. The relationship between London and Madras was turned upside down. For a while, the 
directors of the East India Company as well as the leading ministers in the government lost control, becoming bystanders to a private expansion that changed the British Empire and broke the influence of the East India Company.

\section{SUB-IMPERIALISM}

The changing situation in India and the loss of control over trade and administration in London enabled private merchants and military adventurers to set the local agenda. The hostilities in South India continued after the War of the Austrian Succession, as private interests dragged the Company into regional power politics. The Company had supported the Nawab of Arcot in return for trading privileges, and the private merchants continued the practice. The loss of revenue drove the Nawab, Muhammad Ali, into debts and he was forced to borrow money. The situation was critical because his largest creditors were private merchants and Company servants. As private trade became less remunerative, the Nawab's bonds became the safest and most lucrative investments and his many "presents" were the speediest means of gaining a fortune. With private fortunes depending on the Nawab's ability to repay the money, all British operations around Madras were conducted in the understanding that Arcot had to be protected to secure the investments. Private creditors needed to keep the Nawab afloat thus advancing the territorial expansion of his domain. The private creditors left the field of commerce and became sub-imperialists creating a vast British domain with or without the consent of the directors and the government in London. ${ }^{54}$

Nicholas Morse, the former governor of Fort St. George, who was recalled to London and accused of misconduct during the siege and occupation of Madras, returned to Madras when the directors dropped all charges. The former governor had lost his private fortune during the French occupation and hoped to regain some of his money. In 1755, he oversaw the décor at Chepauk, the palace built by Muhammad Ali. The interior was designed in European style and furnished with odd assortments of English goods, china and paintings. Morse was not particularly impressed with the Nawab and considered him a Company puppet. He felt that the future of South India belonged to the British:

The country government must in reality come to an end, and the European take its place, and if both agree then to have a Nabob to preside over that part of the province that may be undivided, subject to their council. It may serve to exhibit to the Empire a new form of government. ${ }^{55}$

54. P. Nightingale, Fortune and Integrity. A Study of Moral Attitudes in the Indian Diary of George Paterson 1769-1774, (New Delhi, Oxford University Press 1985), 30; for the sub-imperialism on the Western coast, see P. Nightingale, Trade and Empire in Western India, (Cambridge University Press 1970); L. Subrahmanian, Indigenous Capital and Imperial Expansion: Bombay, Surat and the West Coast (Cambridge: Cambridge University Press, 1996).

55. Morse to Benyon, Madras 20 October 1755, quotation is from, J.D. Gurley, "The Debts of the Nawab of Arcot, 17631776”, unpublished Ph.D. Theses Oxford June 1968, OIOC PHOTO EUR 208, 26. 
The British government had to act on the misconduct in India and demanded regulation and definition of where Company responsibilities ended and those of the British state began. Philip Lawson has argued that the immense value of the Company's activities to British tax and custom revenues could not be jeopardized. It led to a political intervention beginning in 1773 that changed the nature of the Company's role within Britain and the trading community at large. ${ }^{56}$

One of the consequences of sub-imperialism was the creation of agency houses. As Holden Furber has pointed out, private British agency houses in India were a natural consequence of the practice pursued by merchants returning to England of leaving capital invested in Asian commerce in the care of specially appointed attorneys. According to Furber, agency houses were "a consequence of the closer links forged between country trade and Europe trade by the growth of an empire of conquest in India." ${ }^{\prime 2}$ An interesting aspect concerning agency houses is that, like the chartered company, they separated capital from ownership. Investors in an agency house did not control the administration of the funds; they received an annual dividend from the investment. This practice differed from that of the commission system, in which merchants controlled their capital and gave orders to the commissioner as to how the money was to be invested. Although the commercial organization of the Company was abolished, its most vital structures survived in the agency houses.

In his Inquiry into the Nature and Causes of the Wealth of Nations (1776), Adam Smith reflected over the progress of societies and argued that nations must go through four stages of development, each of which will shape the mode of production and political institutions. The final state is characterised by the division of labour and free trade between nations, effectively suspending mercantilism. ${ }^{58}$ The rights-for-revenue deals belonged to the past. Free trade and liberalism became the new deal between the state and its merchants.

\section{Conclusion}

Emphasising the positive effects of the cooperation between the state and private entrepreneurs "rights for revenue", as argued by Michael Pearson, is useful in the description of British commercial expansion. In the period between 1600-1750 the state traded off commercial rights in need of cash. The pursuit of private aims was a fundamental drive behind the establishment of British trade and settlement in Asia and the privileges were shared by many, although they in the case of the East India Company, were given to the

56. P. Lawson, The East India Company, 125.

57. H. Furber, Rival Empires of Trade in the Orient, (Minnesota: University of Minnesota Press, 1976), 290.

58. S. Mentz, "Finance", eds. P. Levine and J. Marriott, The Ashgate Research Companion to Modern Imperial Histories, (London: Ashgate, 2014), 338. 
few. Company servants and private merchants operated under the protective umbrella of the East India Company and wove, according to Erikson and Bearman, "local interactions into a global institution creating the dense structures we associate with globalizing processes on the back of the existing trade infrastructure." ${ }^{59}$ However, the fiscal need of the British government rose during the eighteenth century and the desire to annex some of the Company's gains for its own budgetary needs upset the old agreements. It was a difficult manoeuvre due to the complexity of the private networks. Through the business papers of William Monson, the historian can describe how sets of private interests characterized the East India Company's affairs in India. The co-existence of different private interests ceased with the French conquest of Madras and in the following decades, the British government became a reluctant bystander to the private plunder in India. A new arrangement was needed. The right to trade was made free. The agency houses took over the commercial activities from the Company, and combined country trade in the Indian Ocean with transcontinental commerce with London. The Company became a territorial ruler, a state within the state, and its employees were no longer merchants but civil servants. The British state regained stability and the late eighteenth-century crisis was followed by a century of rising British power in the world. What happened? According to Huw Bowen, "the metropolitan elites who had established the original structure would now set about using the same foundations and many of the same basic materials to build a new and rather different imperial edifice" ${ }^{60}$. Thus, "rights for revenue" was transformed from a mercantilist policy into a liberal framework of free trade and open markets. 